\title{
Cultural Adaptations to the Measurement of Attitudes to Ageing: Psychometric Assessment of the Malay Reactions to Ageing Questionnaire
}

DOI:

10.1177/1073191118766400

\section{Document Version}

Accepted author manuscript

Link to publication record in Manchester Research Explorer

Citation for published version (APA):

Mohd Faudzi, F. N. B., Armitage, C. J., Bryant, C., \& Brown, L. (2018). Cultural Adaptations to the Measurement of Attitudes to Ageing: Psychometric Assessment of the Malay Reactions to Ageing Questionnaire. Assessment. https://doi.org/10.1177/1073191118766400

\section{Published in:}

Assessment

\section{Citing this paper}

Please note that where the full-text provided on Manchester Research Explorer is the Author Accepted Manuscript or Proof version this may differ from the final Published version. If citing, it is advised that you check and use the publisher's definitive version.

\section{General rights}

Copyright and moral rights for the publications made accessible in the Research Explorer are retained by the authors and/or other copyright owners and it is a condition of accessing publications that users recognise and abide by the legal requirements associated with these rights.

\section{Takedown policy}

If you believe that this document breaches copyright please refer to the University of Manchester's Takedown Procedures [http://man.ac.uk/04Y6Bo] or contact uml.scholarlycommunications@manchester.ac.uk providing relevant details, so we can investigate your claim.

\section{OPEN ACCESS}




\title{
Cultural Adaptations to the Measurement of Attitudes to Ageing: Psychometric Assessment of the Malay Reactions to Ageing Questionnaire
}

\begin{abstract}
This is a pre-copyedited, author-produced PDF of an article accepted for publication in the journal 'Assessment' in February 2018, following peer review. The final published version of the article will be available from the publisher's website: http://journals.sagepub.com/home/asm
\end{abstract}

\author{
Farah Nadia M.Faudzi ${ }^{1}$, Christopher J. Armitage ${ }^{1,2,3}$, Christina Bryant ${ }^{4}$, Laura J.E. \\ Brown* ${ }^{1}$ \\ ${ }^{1}$ Manchester Centre for Health Psychology, Division of Psychology and Mental Health, University of \\ Manchester, UK. \\ ${ }^{2}$ NIHR Manchester Biomedical Research Centre, Manchester University NHS Foundation Trust, \\ Manchester Academic Health Science Centre, UK \\ ${ }^{3}$ NIHR Greater Manchester Patient Safety Translational Research Centre \\ ${ }^{4}$ Melbourne School of Psychological Sciences, University of Melbourne, Melbourne, Australia
}

\footnotetext{
*Address correspondence to Laura J.E. Brown, Manchester Centre for Health Psychology, Division of Psychology and Mental Health, and The University of Manchester, Zochonis Building, Manchester, M13 9PL. E-mail: laura.brown@manchester.ac.uk
}

\section{Acknowledgments}

We thank the study participants and the managers of the participating organizations for their contribution to this study. 


\begin{abstract}
The aims of this study were to culturally-adapt the Reactions to Ageing Questionnaire (RAQ) for a non-Western (Malay) population, and explore attitudes to ageing in relation to age, gender and education. Eight new culturally-relevant items were generated by asking Malay-speaking participants about their reactions to ageing. A Malay version of the extended 35-item RAQ was then administered to 911 Malaysian participants aged 1860 years. Exploratory factor analysis revealed four factors. Three of the factors were similar to those identified in the original RAQ, whilst 'Family and Religion' emerged as a new factor. More negative attitudes to ageing were observed in younger and women respondents. There were no effects of education. This culturally-adapted RAQ exhibits robust psychometric properties, and could be used to assess attitudes to ageing in Malaysia and other Southeast Asian countries. Moreover, we have identified a "core set" of RAQ items with that could be applicable worldwide.
\end{abstract}

Key words: Validation, Reliability, Attitudes to Ageing, Self-Perception, Personal Ageing 


\section{Introduction}

Attitudes to ageing are defined as feelings, cognitions and behaviours related to the process of ageing as a personal experience (Hess, 2006), including the views, interpretations, experiences, expectations and concerns that an individual holds about their own ageing (Janeckova, Dragomirecka, Holmerova \& Vankova, 2013; Levy, 2003; Steverink, Westerhof, Bode \& Dittmann-Kohli, 2001). Attitudes to ageing can be held both by people who have already experienced ageing (e.g. those over 60 years of age: United Nation, 2013), and by those who are younger (Kornadt \& Rothermund, 2015). However, the nature and determinants of these attitudes are understood to differ in some important ways. In particular, as people get older, their attitudes may be informed by their personal experiences of age-related changes (O'Hanlon \& Coleman, 2008), such as to their appearance (e.g., wrinkled skin and graying hair), functioning (e.g., reduced stamina) or health (Diehl, Brothers, Wahl \& Miche, 2015). In contrast, attitudes to ageing held in younger life are more likely to be informed by observations of other people's ageing (Gilbert \& Ricketts, 2008), or from cultural stereotypes of old age (Levy, 2009), and thus are comprised of expectations, hopes, and fears about how the self and life will be in later life (Kornadt, Voss \& Rothermund, 2015).

Empirical studies have shown that negative attitudes to ageing held by adults in younger life can have important consequences for future health and well-being. For example, Klusmann, Sproesser, Wolff and Renner (2017) showed that positive attitudes to ageing at baseline predicted healthier eating patterns over a one-year follow-up period in both middle-aged (36-64 years) and younger (18-35 years) adults, even after controlling for participants' gender and baseline eating behaviour, health, and BMI. More positive attitudes to ageing in middle-aged adults of good health have also been shown to be positively associated with levels of sporting 
activity six years later (Wurm, Tomasik \& Tesch-Romer, 2010). Such associations between attitudes to ageing and engagement in health behaviours highlight the importance of understanding the content and valence of attitudes to ageing held by people before they reach later life.

There is evidence that attitudes to ageing held before old age can be influenced by a range of demographic variables, including age, gender, and education level. For instance, previous studies have demonstrated that attitudes tend to be more negative at younger ages (Abraham \& Silverstein, 2006; Draper, Gething, Fethney \& Winfield, 1999; Golden, Gammonley, Hunt, Olsen, \& Issenberg, 2013; Mosher-Ashley \& Ball, 1999; Usworth, McKee \& Mulligan, 2001) and among women (Abraham \& Silverstein, 2006; Barret \& Von Rohr, 2008; Cumming \& Kropf \& DeWeaver, 2000; Draper et al.,1999; Golden et al, 2013). These findings are consistent with the notion that anxiety towards an anticipated event (in this case ageing) is greater than when that event is actually experienced (Yan, Silverstein \& Wilber, 2011), and that the anticipation of ageing may be more negative for women due to cultural preferences for youthfulness (Armitage, 2016) and physical appearance (Barret \& Vohn Rohr, 2008). The influence of education in adults younger than 60 years is less clear: although studies with middle aged participants have shown higher levels of education to be associated with more positive attitudes to ageing (Joshi, Malhotra, Lim, Ostbye \& Wong, 2010), studies with a broader range of younger participants (e.g. aged $15-69$ years) have found no effects of education on attitudes to ageing (Gething, 1994; Gething, Fethney, Mckee, Goff, Churchward \& Matthews, 2002; Gething et al., 2004). One reason for this discrepancy in the effects of education could be that the younger populations in the studies by Gething (1994) and Gething et al. (2002; 2004) were 
healthcare workers, who are more likely than the general population to have higher levels of education.

Despite the importance of measuring attitudes to ageing in younger populations, most of the commonly-used measures have been specifically developed for use with older adults (i.e., those aged over 60). For instance, the Attitudes to Ageing Questionnaire (AAQ: Laidlaw, Wang, Coelho \& Power, 2007) and the Aging Perceptions Questionnaire (APQ; Barker, O'Hanlon, McGee, Hickey \& Conroy, 2007) ask older participants to reflect on their own experiences of ageing, and so are not suitable for younger individuals who have yet to experience the ageing process. The Reactions to Ageing Questionnaire (RAQ) is one of the few measures of attitudes to ageing that has been designed to be administered to people aged under 70 (Gething, 1994), and operationalises attitudes to personal ageing in terms of an individual's anticipations of their future characteristics when they are old (Koder \& Helmes, 2008a). The RAQ was first developed from open-ended responses about how nurses felt about ageing, and then validated using a sample of 531 health care specialists and a general population sample aged 15-69 years. Psychometric analysis of this original 27-item version revealed six factors: Anxiety about the Future; Physical Well-being; Psychological Well-being; Denial of Ageing; Isolation; and Activity (Gething, 1994).

The RAQ has been validated for use in Australia (Koder \& Helmes, 2006; 2008a; 2008b; Netz, Guthrie, Garamszegi \& Dennerstein, 2001; Gething et al., 2004), Canada (Helmes \& Pachana (2015), the UK (Gething et al., 2004; Unsworth et al., 2001) and Sweden (Gething et al., 2004). However, there are inconsistencies in the numbers and content of the factors extracted, with some studies extracting as few as three factors (Koder \& Helmes, 2006; 2008a; Gething et al., 2004; Wells, Foreman, Gething \& Petralia, 2004), and others identifying four 
(Koder \& Helmes, 2008b) or five factors (Netz et. al., 2001; Usworth et al., 2001). Some items have also shown low factor loadings (Gething, 1994; Netz et al., 2001), and have been removed (Gething et al., 2004; Unsworth et al., 2001). Taken together, these inconsistencies in factor structure and weak factor loadings, suggest that more validation work is needed to refine the content of the scale.

To develop a full understanding of how attitudes to aging form, develop, and influence future outcomes, it is important to look beyond Western populations (e.g. those in North America, Australasia, and Europe). It is therefore notable that the RAQ has not yet been tested in a non-Western country. Given that the original RAQ items were generated by Western participants, the content of the RAQ is also likely to be biased towards a Western understanding of ageing. This omission is important because research to date suggests that there may be key differences between Western and non-Western societies in the ways they perceive ageing and older people (Lockenhoff, Lee, Buckner, Moreira, Mertinez \& Sun, 2015). For instance, Western populations, with more individualistic values, tend to value older adults less highly and attach greater importance to self-fulfilment, freedom and individuality (Wang \& Mallinckrodt, 2006). In contrast, Eastern populations (e.g., Southeast Asian and Middle Eastern) tend to hold more collectivistic values that play important roles in guiding intergenerational relations, in which adults are expected to be considerate, respectful and supportive towards their parents (Kim, Cheng, Zarit \& Fingerman, 2015).

Malaysia can be considered representative of Southeast Asia, a region that has a land mass of 4.5 million $\mathrm{km}^{2}$ (10.5\% of Asia), is home to 641.8 million people, and includes countries such as Singapore, Thailand and Indonesia as well as Malaysia (World Population Prospect, 2017). Malaysia is typical of this region in terms of gross domestic product per capita $(\$ 26,141$ 
versus mean $\$ 22,777$ for the Southeast Asian region: International Monetary Fund, 2017) and subjective well-being $(M=7.13$ versus $M=7.21$ for other Southeast Asian countries: World Values Survey, 2017). Moreover, consistent with the idea of "Eastern values", compared with "Western values", Malaysian citizens strongly endorse collectivistic values (Kunhen et al., 2001), routinely practice values of filial piety (Damulak, Minhat \& Rahman, 2015), engage in high levels of caregiving (Minhat, Hamizah \& Nor Afiah, 2015a), show high levels of family support (Teh, Tey \& Ng, 2014), and a high proportion of them live with elderly relatives (Kooshiar, Yahaya, Hamid, Abu Samah \& Jou, 2012). Malaysian people are also more likely to hold conservative values, and are keener to teach values of thrift and hard work in their offspring, compared to people in the West (Bomhoff \& Gu, 2012).

Given the cultural differences between Eastern and Western cultures, simple translation of the RAQ from English is unlikely to capture sufficiently the content of the attitudes held by a non-Western population (Schellingerhout, Heymans, Verhagen, de Vet, Koes \& Terwee, 2011). Instead, measures of attitudes to ageing will likely require some cultural adaptation to ensure that they fully capture the attitudes held by the population of interest. For this reason, the aims of the present study were to culturally-adapt and validate a Malay version of the RAQ, and then explore the effects of key demographic variables (age, gender, and education, which are among the most frequently explored variables in Western populations) on attitudes to ageing. In order to achieve this aim, we first generated potential new items for the RAQ by asking Malay participants to report their thoughts and feelings about their own ageing. A Malay-language version of this culturally-adapted scale was then administered to a large sample of Malay participants aged 1860 years of age. Given the known relationships between attitudes to ageing and age and gender 
(Draper et al., 1999; Golden et al, 2013), we expected that older participants and men would have more positive attitudes to ageing. The effect of education was also explored.

\section{Method}

\section{Participants}

Participants in the present study were employees of public sector organizations around Kedah, the Northern region of Peninsular Malaysia. Public rather than private sector organizations were approached because the Ministry of Information was able to supply a list of all such organisations, making it possible to approach all organisations, and minimise the risk of selection bias. According to the Department of Statistics, Malaysia (2016), about 1.65 million people (12.2\%) work in this sector out of 13.5 million employees in Malaysia. Inclusion criteria for the present study were: 1) to be an employee aged 18 to 60 years old, and 2) to be fluent in the Malay language, with self-reported language proficiency at either level 4 (full professional proficiency) or 5 (native proficiency) (Interagency Language Roundtable, 2016).

\section{Materials}

\section{- Cultural-Adaptation of the RAQ}

The original 27-item RAQ (Gething et al., 2004) was first translated into the Malay language using an English-Malay-English back translation procedure (Ozolins, 2009). Members of the research team compared the original and the back-translated English versions to identify any differences in the meanings of the items. Any problems were then resolved through discussions between a Malay-English bilingual linguistics scholar and members of the research team. As a final check for clarity, this revised translated version was then administered to 18 Malay-speaking participants living in the North West of the UK. These participants were 
purposively recruited to ensure approximately equal numbers of women $(n=10)$ and men $(n=$ 8); and a spread of age ranges (18-29 $(n=6), 30-39(n=7), 40-49(n=3)$ and 50-60 $(n=2))$ and ethnicities (Malay $(n=14)$, Chinese $(n=3)$ and Indian $(n=1))$. All participants were native Malay speakers who were born in Malaysia and had spent fewer than five years in the UK.

Participants were asked to 'think aloud' (Kaklamanou, Armitage \& Jones, 2013) when completing the questionnaire. This required the participants to complete the questionnaire whilst telling the researcher everything they were thinking as they did so. Any ambiguities or misunderstandings about the items arising from this procedure were then addressed through discussion within the research team.

Candidate new items for inclusion in the culturally-adapted version of the Malay RAQ were identified by asking the same 18 participants to respond to an item in the Malay language that asked them to: "Imagine that you are over the age of 65 . Tell me how you feel about your own ageing". This open-ended question was based on that used by Gething (1994) when developing the original version of the RAQ. Although the precise question used to elicit participants' responses was not reported, Gething (1994, p.77) states that participants 'were asked to write open-ended responses about how they felt about their own ageing'. This task was presented before participants completed the Malay translated RAQ in order to prevent their responses from being influenced by the contents of the RAQ.

\section{- Content Analysis of Open-Ended Responses}

In line with the concept mapping of open-ended responses procedure described by Jackson and Trochim (2002), each response to the open-ended question was first split into single concept phrases. These phrases were then sorted into groups of similar statements (themes), and 
the frequency of responses within each theme calculated. This procedure produced eight themes relating to attitudes to ageing (Supplemental materials (i)). The content of the themes was then compared to the existing items of the RAQ to identify any topics that were not sufficiently covered by the existing items, so that candidate new items could be developed, where necessary.

The content of one of these themes (death) was already represented in the original version of the RAQ (e.g: Item 7- I worry about dying and leaving behind those I love), and so no new items related to this theme were generated. An additional four themes (themes 2-5) were already covered in the original RAQ, but the existing items did not capture the full breadth of participants' responses. For example, although the physical appearance (theme 2) theme was partly covered in the original RAQ (item 21: I won't like growing old), the item did not refer to physical appearance, and so a new item was generated to capture this (I won't like looking old). Theme 3 (health), was covered by a number of items in the original RAQ (e.g.: Item 2- I worry that I might become senile and lose my mind; Item 17- I worry about becoming frail), but none of these items related to the more general health worries reported by our participants, and so a new item was generated to capture this (I worry about my health getting worse). For theme 4 (ability to do desirable things), item 25 of the original RAQ, 'there is a lot to look forward to in regard to being old' was relevant, but very general, and did not specifically mention being able to undertake desirable activities. Therefore, a more specific new item ('I will have more time to do things that I enjoy') was generated. Two new items were also developed to capture the content of theme 5 (family relationships). This is because participants' responses to this theme mainly focused on family or parent-child relationships, whereas existing relationship items in the RAQ were more general, and seemed to refer more to relationships with partners (e.g: item $16^{\text {' } I}$ look forward to growing old with someone I love'). The final three themes (6-8: religion; 
acceptance of ageing; and financial concerns) were not represented in the original version of the RAQ, and so new items relating to these themes were generated to capture the meaning of participants' responses. The results of content analyses, participants' responses, and the candidate new items generated are presented in the Supplemental materials (i).

The final questionnaire therefore comprised 27 translated items from the original RAQ and eight new items (see Supplemental materials (ii)). Participants were asked to indicate how much they agreed or disagreed with each statement in relation to how they might feel when they are over the age of 65 . Responses were given on a 5-point Likert-type scale ranging from strongly disagree (1)-strongly agree (5). This response scale differed slightly from the 6-point scale used by Gething (1994). This was because the RAQ was administered as part of a larger battery of questionnaires, and a consistent response style between questionnaires was used to minimize the potential for confusion. Eighteen of the 35 items $(2,4,7,8,9,11,13,17,18,19$, $20,21,23,26,27,29,30 \& 31)$ were reverse scored so that a higher score always indicated more positive attitudes. Total scores on the RAQ could therefore range from 35 to 175, with higher scores on all items indicating more positive attitudes to ageing.

\section{Procedure}

The study was approved by the University of Manchester Research Ethics Committee (Reference: 15223) and the Malaysian Economic Planning Unit (MEPU). The data were collected between October and December 2015. Letters asking permission to conduct the study were sent to 68 organisations listed by the Ministry of Information, Kedah, including schools, the immigration department and religious centres. Sixty seven of these organisations agreed to be involved with the study. The researcher then provided packs of questionnaires to the managers of 
each of these organisations. Managers were asked to distribute the questionnaires to all employees in their organization, and ask them to complete and return them within the next two weeks. This approach was taken as using legitimate authority, such as management support, has been found to increase participant response rates, particularly in Asian countries (Krishnan \& Poulose, 2016).

Each questionnaire pack contained a participant information sheet, the culturally-adapted Malay RAQ, demographic questions (date of birth, gender, language proficiency, and levels of education, for which participants indicated which of four categories (high school; certificate/diploma; undergraduate; or postgraduate) best represented their highest level of education), plus a number of other measures of attitudes, health, and well-being that were collected as part of a larger study. The questionnaires were completed anonymously and the participants were asked to seal the opaque envelope provided after the completion of the questionnaire to ensure confidentiality. The researcher subsequently collected the envelopes from the manager.

\section{Data Analysis}

The analyses were carried out using IBM SPSS 23. We first used Exploratory Factor Analysis to examine the basic structure of the culturally-adapted RAQ, and to identify items with low factor loadings. Cronbach's alpha coefficients were then calculated to evaluate internal consistency. The interactions between socio-demographic variables (age, gender, level of education) and the subscales of the RAQ were tested using an alpha value of .05 (i.e., $p<.05$ ), using analysis of variance (ANOVA). To maximise comparability with the original RAQ validation by Gething (1994), four age groups $(18-29,30-39,40-49,50-60)$ were used for these analyses. To minimise 
the number of small sample sizes within each cell of the factorial design (Tabachnick \& Fidell, 1996), the four educational background categories were collapsed into two broader categories of lower (high school and certificate/diploma) and higher (undergraduate/postgraduate) education.

\section{Results}

\section{Participant Characteristics}

Overall, 1731 questionnaire packs were distributed to the managers of the 67 participating organisations. Of these, employees returned 957 questionnaires to their managers. Thirty-one questionnaires contained at least one full scale that had not been completed, and so were excluded from subsequent analyses. Data from an additional nine participants were excluded because they had missed one or more items of the RAQ, and from one participant who was an extreme outlier (more than 3 interquartile ranges from the rest of the scores). The data from a further five participants were excluded for not meeting language inclusion criteria (i.e. indicating that their Malay proficiency was lower than full professional proficiency). The final sample therefore comprised 911 participants (Table 1). The sample size was considered appropriate on the basis of meeting the recommendation by Hair, Black, Babin and Anderson (2014) of achieving a minimum participant: item ratio of 1:20 (i.e. 700 participants for a 35-item measure), and being close to the 1000 participant level that is considered "excellent" (Comree \& Lee, 1992). Ten of these participants did not provide their year of birth. Data for these participants was included in the factor analysis, but not in the analyses involving age.

Table 1 about here.

More women $(n=516)$ than men $(n=395)$ participated in the research (Table 1$)$, whereas national census data indicate that there are 0.84 million men and 0.81 million women employed 
in the public sector (Department of Malaysia Statistics, 2016). In the present study, the majority of participants (94\%) were of Malay ethnicity, followed by Chinese (3.3\%), Indian (2.0\%) and others (1.2\%). These proportions differ slightly from Malaysian population levels, which are reported as $68.6 \%, 23.4 \%, 7.0 \%$ and $1.0 \%$ for Malay, Chinese, Indian and others respectively (Department of Statistics Malaysia, 2016). In terms of education levels, more participants had lower $(n=567)$ than higher levels of education $(n=344)$. Job types were classified into nine categories, as specified by the Malaysian Standard Classification of Occupations (2008). Almost half of the respondents (49.3\%) were categorised as being clerical support workers (e.g., clerks or secretaries), $22.8 \%$ as professionals (e.g., lecturers or engineers), with technicians and associate professionals (e.g., nurses or laboratory assistants) making up the remaining 17.2\%. The present sample differed from the general Malaysian population, with those in lower-level occupations (e.g., cleaner, street vendor, machine operators) being under-represented (Ministry of Human Resources, 2015).

\section{Factorial Structure of the RAQ}

An exploratory factor analysis was conducted on participants' responses to the 35 items of the Malay RAQ. The coefficient value of the Kaiser-Meyer-Olkin test revealed an excellent level of sampling adequacy (0.91), and the Bartlett's Test of Sphericity was statistically significant $(\mathrm{p}<$ $.05)$, suggesting that the data were meaningful. The exploratory factor analysis produced six components with eigenvalues greater than one. However, the scree plot showed a sharp decrease after the fifth factor, suggesting that a four-factor model was more appropriate. This was confirmed by a Monte Carlo Parallel Analysis (MCPA: Ladesma \& Valero - Mora, 2007), which showed that random ordered eigenvalues were below the actual eigenvalues for only four factors. 
As the data were normally distributed, and there are possible correlations among the factors tested, Maximum likelihood (ML) extraction and oblique rotation methods were used (Costello \& Osborne, 2005). These methods are consistent with previous analyses of the RAQ (Gething, 1994; Gething et al., 2004). In order to identify items that most clearly represent the four extracted factors, any items loading less than .45 were excluded. Comrey and Lee (1992) recommend this cut-off on the grounds that only items loading above this value can be considered to be fair descriptors of the underlying construct. Ten items were excluded using this criterion, only one of which was one of the new items generated for the present study (item 32: I will accept the fact that I am old). The other seven new items were retained, indicating a broader relevance of the new items to participants' attitudes to ageing. The final culturally-adapted scale therefore comprised 25 items as shown in Table 2: eleven for 'Negative Thoughts about Growing Older'; three for 'Family and Religion'; six for 'Positive Aspects of Ageing'; and five for the 'Perceived Personal Attributes' factor. Supplemental materials (iii) provide results for the full 35-items.

Table 2 about here

As shown in Table 2, the first, third and fourth factors were similar to those found by Gething et al., (2004), Netz et al. (2001), Koder and Helmes (2006, 2008a; 2008b) and Unsworth et al. (2001), namely 'Negative Thoughts about Growing Older' (Factor 1); 'Positive Aspects of Ageing' (Factor 3) and 'Perceived Personal Attributes' (Factor 4). In particular, 14 of the original items loaded onto the same factors as in previous work, thus representing a possible 'core set' of items that may work well across cultures (Table 2). The second factor represented a novel dimension of attitudes to ageing, namely, 'Family and Religion', which comprised solely of new items generated by Malay participants. 


\section{Internal Consistency}

Overall, the revised Malay version of the RAQ had an internal reliability of $\alpha=.88$. The reliabilities of each subscale ranged from $\alpha=.73$ to .89 (Table 3), indicating good internal consistency (Field, 2005). The 'Negative Thoughts about Growing Older' factor and the 'Perceived Personal Attitudes' factor were strongly correlated with the total RAQ score $(r=.87$ and .77, respectively), while the 'Positive Aspects of Ageing' factor showed a moderate correlation $(r=.55)$. The 'Family and Religion' factor correlated less strongly with total RAQ scores $(r=.21)$. This is probably due to the smaller number of items in this factor, and indicates that the factors may be best considered as separate variables that together form a meaningful construct, rather than interchangeable dimensions (Mokkink et al., 2012).

Table 3 about here

\section{Demographic Differences in Total Reactions to Ageing Scores}

The effects of demographic variables on overall RAQ scores were analysed using a 4 (age group: 18-29 vs. $30-39$ vs. $40-49$ vs. $50-60) \times 2$ (gender: women vs. men) $\times 2$ (education level: low vs. high) analysis of variance (ANOVA). There was a significant main effect of age group, $F$ (3, $885)=6.413, p<.001, \eta_{p}{ }^{2}=.021$. Post hoc Scheffe tests revealed that attitudes to ageing were significantly $(p<.05)$ more positive in the oldest age group $(50-60: M=83.97, S D=1.04)$ compared to the two younger age groups $(18-29: M=78.53, S D=0.74, d=6.03 ; 30-39: M=$ 79.85, $S D=0.64, d=4.77)$. However, there were no differences in scores between the 40-49 $(M$ $=80.91, S D=0.89)$ and 50-60-year age groups, or between the 18-29 and 30-39 year age groups. There was also a significant main effect of gender, $F(1,885)=4.192, p=.041, \eta_{p}{ }^{2}=.005$, with men reporting more positive attitudes $(M=81.67, S D=0.58)$ than women $(M=79.95, S D=$ 
0.61). There was no significant main effect of education levels, $F(1,885)=1.421, p=.234, \eta_{p}{ }^{2}$ $=.002$, and no significant interactions. Mean scores for all levels of each factor are presented in Table 4 .

Table 4 about here

\section{Reactions to Ageing Subscales}

A three-way univariate ANOVA was conducted for each of the four subscales of the Malay RAQ, in order to observe the effects of age, gender and education levels. To facilitate comparison between subscales with different numbers of items, mean scores for each subscale were calculated per item (i.e., out of a maximum of 5). Note that higher scores for each subscale indicate more positive attitudes to ageing.

\section{Negative Thoughts about Growing Older}

With regards to negative thoughts about growing older, there was a significant main effect of age group, $F(3,885)=4.540, p=.004, \eta_{p}{ }^{2}=.015$. Post-hoc Scheffe tests showed that scores in the oldest group (50-60: $M=2.92, S D=0.06)$ were significantly higher (reflecting more positive attitudes to ageing) than the youngest two age groups $(18-29: M=2.66, S D=0.04, d=5.10 ; 30$ 39: $M=2.68, S D=0.04, d=4.71)$. There was also a significant main effect of gender, $F(1,885)$ $=6.429, p=.011, \eta_{p}{ }^{2}=.007$, with higher scores on this subscale in men $(M=2.81, S D=0.03)$ compared to women $(M=2.68, S D=0.04)$ (Table 4). There was no main effect of education levels, $F(1,885)=2.860, p=.091, \eta_{p}{ }^{2}=.003$, and no significant interactions between variables.

\section{Positive Aspects of Ageing}

For positive aspects of ageing, there was a significant main effect of age group $F(1,885)=$ 
7.695, $p<.001, \eta_{p}{ }^{2}=.025$. Scheffe tests showed that, as with the Negative Thoughts about Growing Older factor, positive aspects of ageing scores were significantly higher (indicating more positive attitudes to ageing) in the oldest group (50-60: $M=3.60, \mathrm{SD}=0.05)$ compared to people in the 18-29 $(M=3.35, S D=0.04, d=5.52)$ and 30-39 $(M=3.45, S D=0.03, d=3.31)$ groups. Scores were also significantly higher in people aged 40-49 $(M=3.54, S D=0.04)$ compared to people aged 18-29 $(d=4.75)$ (Table 4$)$. No other groups were significantly different from one another. There were no significant main effects of gender, $F(1,885)=3.006, p=.083$, $\eta_{p}{ }^{2}=.003$; or education levels, $F(1,885)=0.024, p=.876, \eta_{p}{ }^{2}=.001$, and no significant interactions.

\section{Perceived Personal Attributes}

For the Perceived Personal Attributes domain, there were no main effects of age group $F(3,885)$ $=1.603, p=.187, \eta_{p}{ }^{2}=.005$; gender $F(1,885)=0.130, p=.719, \eta_{p}{ }^{2}=.001 ;$ or education $F(1$, $885)=.557, p=.456, \eta_{p}{ }^{2}=.001 ;$ and no significant interactions between them.

\section{Family and Religion}

For the Family and Religion factor, there were no significant main effects of age group $F$ (3, $888)=0.757, p=.518, \eta_{p}{ }^{2}=.003$; gender, $F(3,885)=1.804, p=.180, \eta_{p}{ }^{2}=.002$; or education levels, $F(1,885)=1.466, p=.226, \eta_{p}{ }^{2}=.002$; and no interactions between these variables.

\section{Discussion}

The aims of this study were to develop a culturally adapted Malay version of the RAQ, and to explore the effects of key demographic variables on RAQ scores in adults younger than 60 years of age. An exploratory factor analysis revealed four factors, including a 'Family and Religion' 
factor that has not been identified in Western versions of the RAQ. Items with low factor loadings were deleted, resulting in high levels of internal consistency across the remaining scale and subscales. Overall, the total Malay RAQ scores were significantly affected by age and gender, in that men and older people had more positive attitudes to their ageing. Age and gender effects were also observed for some of the sub-scales, but no effects of education were seen for any subscale. Together, these results suggest that this culturally-adapted Malay version of the RAQ provides a reliable measure of attitude to ageing that is differentially sensitive to age and gender.

Three of the four factors identified (Negative Thoughts about Growing Older; Perceived Personal Attributes and Positive Aspect of Ageing) were conceptually similar to those found by Gething et al. (2004); Koder and Helmes (2006; 2008a; 2008b); Netz et al. (2001) and Unsworth et al. (2001) in Australian, British and Swedish samples, although the precise contents of the scales differed for some factors. In particular, six items were identified in this study as loading on the 'Perceived Personal Attributes' factor, whereas Gething et al. (2004); and Netz et al. (2004) only found three items, whilst Unsworth et al. (2001) found four items. Moreover, two of the six items that loaded onto the 'Perceived Personal Attributes' factor in the current study (' $I$ find the thought of growing older is depressing'; and 'I won't like growing old') loaded onto the 'Negative Thoughts about Growing Older' by Gething et al. (2004) and Netz et al. (2004). Items loading on the 'Positive Aspects of Ageing' factor were generally consistent with the findings from Gething et al. (2004); Netz et al. (2001) and Unsworth et al. (2001). The content of the 'Negative Thoughts about Growing Older' factor was also similar to that reported by Gething et al. (2004), although it contained items that made up two different scales (Negative Thoughts about Growing Older and Fear of Becoming Frail) in data from Netz et al. (2001). In addition, 
of the nine original RAQ items that were removed in the current study, four of these (items 6,15 , 16 and 22) were also removed due to their low factor loadings in validations with Australian, Swedish and British participants (Gething et al., 2004), whilst a further five of the items were shown to load poorly onto factors in at least one other Western population (Gething et al., 2004; Unsworth et al., 2001). Taken together, these findings suggest that at least some of the original items of the RAQ show consistency across Eastern and Western populations, and that could be investigated as a potential "core set" of RAQ items that are applicable worldwide.

A new dimension of 'Family and Religion' was identified in this culturally-adapted scale. This factor reflects the concept of a strong family relationship that is traditionally embraced by Eastern cultural groups (Lockenhoff et al., 2015). Filial-piety, for example, has become a basic principle of the family system in Malaysia (Ismail, Jo-Pei \& Ibrahim, 2009), where adults are expected to be attentive to, respectful towards, and supportive of, their parents (Kim et. al., 2015). People in Malaysia also still emphasize the importance of family relationships (Minhat et al., 2015a; Teh et al., 2014). Consistent with this, Kooshiar et al. (2012) reported that about 70\% of older Malaysians live with their adult children, providing companionship for the older people, and enabling interaction and contact across generations. Additionally, this factor reflects the significant role that religion plays in the Malaysian population (Abu Bakar, 2013), which is believed to facilitate adjustment to the ageing process (Jianbin \& Mehta, 2003). The link between religious practice and family is also supported by the close relationships between them that often occur in day-to-day life. For instance, individuals often pray for a happy and healthy family, and for the wellbeing of their descendants (Tohit, Browning \& Radermacher, 2012). Elders in the family also play a central role in transmitting religious beliefs to their offspring, such as informing their children about religious rituals and traditions (Mehta, 1997). 
Another contribution of the present study was the examination of the relationships between RAQ scores and demographic variables. The results are broadly in line with previous findings into the relationship between age and RAQ scores in Western populations (Draper, et al., 1999; Golden et al., 2013; Unsworth et al., 2001), which indicate that attitudes to ageing are more positive among older people. In the current study, these effects of age were only seen in two of the four RAQ subscales (Negative Thoughts about Growing Older; Positive Aspects of Ageing), with attitudes towards 'Perceived Personal Attributes' and the 'Family and Religion' aspects of ageing being more consistent across age groups. This is consistent with previous findings suggesting that the effects of age may be limited to certain aspects of attitudes to ageing (Unsworth et al., 2001), and that younger people in Malaysia express concerns about being old that manifest as declining physical ability, health, and changes in physical appearances, as well as being more sensitive (Minhat et al., 2015b). The lack of age effect in the Family and Religion factor may be due to the traditional cultural beliefs around filial piety (Damulak et al., 2015) and religion in Malaysia that are emphasized and transmitted in childhood, and reinforced in adulthood (Mehta, 1997), making the positive roles of family and religion similarly salient to people of different age groups.

Consistent with previous studies that have explored the RAQ (e.g., Draper et al., 1999; Golden et al, 2013), attitudes to ageing were also linked to gender in the present study, with men, overall, reporting more positive attitudes compared to women. However, in the current study, gender effects were only seen in the 'Negative Thoughts about Growing Older' subscale, which focuses on age-related changes in cognitive and physical functioning, such as health status, frailty, safety, mortality, and independence. This is consistent with work reporting that men have fewer anxieties about declining cognitive and physical abilities than women (Barrett \& Von 
Rohr, 2008). Similarly, women may find it more challenging to overcome the negative attitudes held about their ageing due to the increased emphasis that is placed on beauty and youth for women: a so-called 'double standard of ageing' (Halliwell \& Dittmar, 2003). Women may also have greater exposure to negative aspects of ageing due to their increased levels of experience in dealing with disabled older parents (Hequembourg \& Brallier, 2005). Indeed, in Malaysia, women are traditionally more involved in caring for elderly parents (Alavi \& Sail, 2010), and are highly concerned about their physical changes (Minhat et al., 2015a; 2015b). This may help to explain why Malaysian women may feel more anxious about their personal ageing, and have more negative expectancies about their personal ageing process, compared to men. The finding that gender effects were limited to just one of the four RAQ sub-scales also highlights the importance of measuring attitudes at this more focused level of description. Education levels did not influence RAQ scores, which chimes with a broader picture of a lack of association between education and RAQ scores in other populations (Gething, 1994; Gething et al., 2002; Gething et al., 2004).

Although the present research takes the literature on attitudes to ageing forward in important respects, some limitations need to be acknowledged. First, the new items generated and added to the scale were based on responses from a relatively small number of participants, who were currently living in the UK, and so may not fully reflect attitudes to ageing held by people in Malaysia. However, these participants were purposefully sampled to be demographically diverse, ensuring at least some variety in the views expressed. Other limitations relate to the sample used to validate the Malay RAQ. For one thing, whilst asking managers of the organizations to distribute the surveys will likely have increased the response rate (Krishnan \& Poulose, 2016), it may also have introduced some sampling or response biases, for instance 
due to managers purposefully targeting or avoiding certain employees. Furthermore, although the sample was large, it consisted almost exclusively of government employees, who were predominantly ethnically Malay. Although this homogeneity made it easier to determine the effects of age, gender and education, it also limits the generalizability of our findings to other ethnicities, or to unemployed or self-employed individuals. In particular, as government employees in Malaysia have to achieve a minimum level of education of high school in order to take on these positions (Malaysia Public Service Department, 2017), participants with very low levels of formal education were not included, and so the full effect of education levels could not be examined. Our use of a categorical measure of education, rather than a continuous one, such as years of education, will also have reduced the sensitivity of our analyses involving educational level. The cross sectional nature of the data also means that it is not possible to establish the extent to which differences between age groups truly represent the effects of age, rather than generational differences. This is particularly important given that longitudinal studies assessing participants' reflections on their experiences of ageing show a trend towards more negative attitudes to ageing with increasing age (Miche, Elsasser, Schilling, \& Wahl, 2014), suggesting that similar effects could be present when assessing participants' attitudes to their future ageing. Finally, the present study only investigated some of the factors that may be related to attitudes to ageing. Future studies that examine whether such responses are also dependent on other factors, such as personality or health, would now be beneficial in order to gain a more complete understanding of the factors that relate to attitudes to ageing in those aged under 60 . 


\section{Conclusion}

The present study identified an additional element of attitudes to ageing not currently captured in Western measures, namely, 'Family and Religion' and demonstrated that the culturally-adapted Malay RAQ had good levels of reliability and validity among Malay adults aged under 60. In addition, the present study provides evidence that, as seen in other cultures, attitudes to ageing are influenced by age and gender, but that levels of education seem to be unrelated to attitudes to ageing in adults aged under 60. Perhaps more importantly, we identified a "core set" of RAQ items that seem to work across cultural settings and would be amenable to testing worldwide.

\section{Declaration of Conflicting Interests}

The author(s) declared no potential conflicts of interest with respect to the research, authorship, and/or publication of this article.

\section{Funding}

The research was supported by the NIHR Manchester Biomedical Research Centre and the NIHR Greater Manchester Patient Safety Translational Research Centre, and a PhD studentship from the Malaysian Ministry of Education awarded to FNMF. 


\section{References}

Abu Bakar, I. (2013). The religious tolerance in Malaysia: An exposition. Advances in Natural and Applied Sciences 7, 90-97.

Abramson, A., \& Silverstein, M. (2006). Images of aging in America 2004. Washington, DC: AARP and University of Southern California

Alavi, K., \& Sail, R.M. (2010). Roles of Malay women in the process of caring for elderly parents: dilemma and challenges in the era of globalisation. Kajian Malaysia, 28, 71-105.

Armitage, C. J. (2016). A brief psychological intervention to protect subjective well-being in a community sample. Quality of Life Research, 25, 385-391. doi:10.1007/s111360151076 6

Barker, M., O’Hanlon, A., McGee, H.M., Hickey, A., \& Conroy, R.M. (2007). Cross-sectional validation of the Aging Perception Questionnaire: A multidimensional instrument for assessing self-perceptions of aging. BMC Geriatrics, 7, 1 - 13. doi:10.1186/14712318-7-9

Barrett, A.E., \& Von Rohr, C. (2008). Gendered perceptions of aging: An examination college students. The International Journal of Aging \& Human Development, 67, 359-386. doi: 10.2190/AG.67.4.d

Bomhoff, E.J., \& Gu, M.M-L. (2012). East Asia remains different: A comment on the index of 'self-expression values' by Inglehart and Welzel. Journal of Cross-Cultural Psychology, 43, 372-383. doi: 10.1177/0022022111435096

Comrey, A.L., \& Lee, H.B. (1992). A first course in factor analysis. Hillsdale, NJ: Erlbaum. 
Costello, A. B., \& Osborne, J.W. (2005). Best practices in exploratory factor analysis: four recommendations for getting the most from your analysis. Practical Assessment Research \& Evaluation, 10, 1-9.

Cummings, S. M., Kropf, N. P., \& De Weaver, K. L. (2000). Knowledge of and attitudes toward aging among non-Elders: Gender and race differences. Journal of Women \& Aging, 12, 77-91. doi: 10.1300/J074v12n01_06

Damulak, P.P., Minhat, H.S., \& Rahman A.A. (2015). Attitude towards the elderly among healthcare related students in Malaysia. International Journal of Health Sciences and Research, 5, 248- 258.

Department of Statistics Malaysia. (2016). Official Portal. Current population estimates in Malaysia, 2014-2016. Retrieved from https://www.dosm.gov.my

Diehl, M., Wahl, H., Brothers, A., \& Miche, M. (2015). Subjective aging and awareness of aging: Toward a new understanding of the aging self. Annual Review of Gerontology \& Geriatrics, 35, 1-X. doi: 10.1891/0198-8794.35.1

Draper, B., Gething, L., Fethney, J., \& Winfield, S. (1999). The senior Psychiatrist survey III: attitudes towards personal ageing, life experiences and psychiatric practice. Journal Australian and New Zealand Journal of Psychiatry, 33, 717-722. doi:10.1080/j.1440 1614.1999.00609.x

Field, A.P. (2005). Discovering statistics using $\operatorname{SPSS}\left(2^{\text {nd }}\right.$ Eds.). London: Sage. 
Gething, L. (1994). Health professional attitudes towards ageing and older people: preliminary report of the Reactions to Ageing Questionnaire. Australasian Journal on Ageing, 13, 77 - 81. doi:10.1111/j.1741-6612.1994.tb00646.x/full

Gething, L., Fethney, J., Mckee, K., Goff, M., Churchward, M., \& Matthews, S. (2002). Knowledge, stereotyping and attitudes towards self-ageing. Australasian Journal on Ageing, 21, 74-79. doi:10.1111/j.1741-6612.2002.tb00421.x

Gething, L., Fethney, J., Mckee, K., Persson, L.O., Goff, M., Churchward, M., \& Matthews, S. et al., (2004). Validation of the reactions to ageing questionnaire. Assessing similarities across several countries. Journal of Gerontological Nursing, 30, 47-54. doi:10.3928/0098-9134-20040901-09

Gilbert, C.N., \& Ricketts, K.G. (2008). Children's attitudes toward older adults and aging: A synthesis of research. Educational Gerontology, 34, 570-586. doi: $10.1080 / 03601270801900420$

Golden, A. G., Gammonley, D., Hunt, D., Olsen, E., \& Issenberg, S. B. (2013). The attitudes of graduate healthcare students toward older adults, personal aging, health care reform, and inter-professional collaboration. Journal of Inter-professional Care, 28, 40-44. doi:10.3109/13561820.2013.830595

Hair, J.F., Black, W.C., Babin, B.J., \& Anderson, R.E. (2014). Multivariate data analysis (7 ${ }^{\text {th }}$ Eds.). Essex: Pearson Education Limited. 
Halliwell, E., \& Dittmar, H. (2003). A qualitative investigation of women's and men's body image concerns and their attitudes toward aging. Journal of Research Sex Roles, 49, 675684. doi:10.1023/B:SERS.0000003137.71080.97

Helmes, E., \& Pachana, N.A. (2015). Dimensions of stereotypical attitudes among older adults: Analysis of two countries. Geriatric Gerontology International, 16, 1226-1230. doi: 10.1111/ggi.12613

Hess, T.M. (2006). Attitudes toward aging and their effects on behavior. In J.E. Birren, \& K.W. Schaie (Ed.). Handbook of the psychology of aging. (pp. 379-406). San Diego: CA: Academic Press.

Hequembourg, A., \& Brallier, S. (2005). Gendered stories of parental caregiving among siblings. Journal of Aging Studies, 19, 53-71. doi:10.1016/j.jaging.2003.12.001

Interagency Language Roundtable. (ILR) (2016) Retrieved from gov.tilr.org.

International Monetary Fund (2017). World economic outlook database. Retrieved from http://www.imf.org/external/pubs/ft/weo/2017/02/weodata/index.aspx

Ismail, N., Tan, J-P., \& Ibrahim, R. (2009). The relationship between parental belief on filial piety and child psychosocial adjustment among Malay families. Pertanika Journal Social Sciences, 17, 215-224.

Jackson, K.M., \& Trochim, W.M.K. (2002). Concept mapping as an alternative approach for the analysis of open-ended survey responses. Organizational Research Methods, 5, 307-336. doi:10.1177/109442802237114 
Janeckova, H., Dragomirecka, E., Holmerova, I., \& Vankova, H. (2013). The attitudes of older adults living in institutions and their caregivers to ageing. Central European Journal of Public Health, 21, 63-71.

Jianbin, X., \& Mehta, K.K. (2003). The effects of religion on subjective aging in Singapore: An interreligious comparison. Journal of Aging Studies, 17, 485-502. doi:10.1016/S08904065(03)00065-3

Joshi, V. D., Malhotra, R., Lim, J.F.Y., Ostbye, T., \& Wong, M. (2010). Validity and reliability of the expectations regarding aging (ERA-12) instrument among middle-aged Singaporeans. Annals of the Academy of Medicine Singapore, 39, 394-398

Kaklamanou, D., Armitage, C.J., \& Jones, C.R. (2013). A further look into compensatory health beliefs: A think aloud study. British Journal of Health Psychology, 18, 139-154. doi:10.1111/j.2044-8287.2012.02097.x

Kim, K., Cheng, Y-P., Zarit, S.H., \& Fingerman, K.L. (2015). Relationship between adults and parents in Asia. In. C. Sheung- Tak, C. Iris, H.H. Fung, W.L. Lydia, \& W. Jean. Successful aging: Asian perspectives (pp. 101- 120). New York, NY: Springer Dordrencht, Heildelberg.

Klusmann, V., Sproesser, G., Wolff, J.K., Renner, B. (2017). Positive self-perceptions of aging promote healthy eating behavior across the life span via social-cognitive process. Journals of Gerontology: Psychological Sciences. Advance online publication. doi:10.1093/geronb/gbx139 
Koder, D.A., \& Helmes, E. (2006). Clinical psychologists in aged care in Australia: A question of attitude or training? Journal of Australian Psychologists, 41, 179-185.

Koder, D.A., \& Helmes, E. (2008a). Predictors of working with older adults in an Australian psychologist sample: Revisiting the influence of contact. Professional Psychology: Research and Practice, 39, 276-282. doi:10.1037/0735-7028.39.3.276

Koder, D.A., \& Helmes, E. (2008b). Predictors of interest in working with older adults: A survey of postgraduate trainee psychologist. Gerontology \& Geriatric Education, 29, 158171. doi:10.1080/02701960802223233

Kooshiar. H., Yahaya, N., Hamid, T.A., Abu Samah, A., \& Sedaghat, J.V. (2012) Living arrangement and life satisfaction in older Malaysians: The mediating role of social support function. PLoS ONE 7, 1-6. doi:10.1371/journal.pone.0043125

Kornadt, A.E., \& Rothermund, K. (2015). Views on aging: Domain-specific approaches and implications for developmental regulation. Annual Review of Gerontology and Geriatrics, 35, 121-144. doi:10.1891/0198-8794.35.121

Kornadt, A.E., Voss, P., \& Rothermund, K. (2015). Hope for the best, prepare for the worst? Future self-views and preparation for age-related changes. Psychology and Aging, 30, doi:10.1037/pag0000048

Krishnan, T.N., \& Poulose, S. (2016). Response rate in industrial surveys conducted in India: Trends and implications. IIMB Management Review, 28, 88-97. doi:10.1016/j.iimb.2016.05.001 
Kunhen, U., Hannover, B., Roeder, U., Shah, A.A., Schubert, B, Upmeyer, A., \& Zakaria, S. (2001). Cross-cultural variations in identifying embedded figures: Comparisons from the United States, Germany, Russia, and Malaysia. Journal of Cross-Cultural Psychology, 32, 366-372. doi:10.1177/0022022101032003007

Ladesma, R.D., \& Valero- Mora, P. (2007). Determining the number of factors to retain in EFA: an easy-to-use computer program for carrying out Parallel Analysis. Practical Assessment, Research \& Evaluation, 12, 1-11.

Laidlaw, K., Power, M., \& Schmidt, S. (2007). The WHOQOL- OLD Group. The attitudes to ageing questionnaire (AAQ): development and psychometric properties. International Journal Geriatric Psychiatry, 22, 367-379. doi:10.1002/gps.1683

Levy, B.R. (2003). Mind matters: cognitive and physical effects of aging self-stereotypes. Journal of Gerontology, Psychological Science, 58, 203-211. doi:10.1093/geronb/58.4.P203

Levy, B.R. (2009). Stereotype embodiment. A psychosocial approach to aging. Current Directions in Psychological Science, 18, 332 - 336. doi:10.1111/j.1467 8721.2009.01662.x

Lockenhoff, C.E., Lee, D.S., Buckner, K.M.L., Moreira, R.O., Mertinez, S.J. \& Sun, M.Q. (2015). Cross-cultural differences in attitudes about aging: Moving beyond the East-West dichotomy. In.Sheung- Tak, C., Iris, C., Fung, H.H., Lydia, W.L. Jean, W. Successful aging: Asian perspectives (pp. 321-333). New York: Springer Dordrencht, Heildelberg. 
Malaysia Public Service Department (2017). Scheme of service and position. Retrieved from www.jpa.gov.my

Malaysia Standard Classification of Occupations (2008). Malaysia standard classification of occupations $\left(3^{\text {rd }}\right.$ Eds.). Kuala Lumpur: Ministry of Human Resources.

Mehta, K.K. (1997). The impact of religious belief and practices on aging: A cross-cultural comparison. Journal of Aging Studies, 11, 101-114. doi:10.1016/S0890 4065(97)90015-3

Miche, M., Elsasser, V.C., Schilling, O.K., \& Wahl, H-W. (2014). Attitude toward own aging in midlife and early old age over a year 12 year period: examination of measurement equivalence and developmental trajectories. Psychology and Aging, 29, 588-600. doi:10.1037/a0037259

Minhat, H.S., Hamizah, S., \& Nor Afiah, Z. (2015a). A qualitative study on ageing related anxietyamong middle aged women in Malaysia. Malaysian Journal of Public Health Medicine, 15, 1-7.

Minhat, H.S., Hamizah, S., \& Nor Afiah, Z. (2015b). View on ageing: A qualitative study among Malay middle-aged women in urban setting in Malaysia. International Journal of Health Science and Research, 5, 248-256.

Ministry of Human Resources. Job statistics 1/2015. Retrieved from myhos.mohr.gov.my Mokkink, L.B., Terwee, C.B., Patrcik, D.L., Alonso, J., Stratford, P.W., Knol, D.L., et al., (2012). COSMIN Checklist manual. Retrieved from www.cosmin.nl

Mosher-Ashley, P.M., \& Ball, P. (1999). Attitudes of college students toward elderly persons 
and their perceptions of themselves at age 75. Educational Gerontology, 25, 89-102. doi:10.1080/036012799268034

Netz, Y., Guthrie, J. R., Garamszegi, C., \& Dennerstein, L. (2001). Attitudes of middle-aged women to aging: contribution of the Reactions to Aging Questionnaire. Climacteric, 4, 306-313. doi:10.1080/713605141.

O’Hanlon, A., \& Coleman, P. (2008). Attitudes towards aging: Adaptation, development and growth into later years. In. J.F. Nussbaum \& J. Coupland $\left(2^{\text {nd }}\right.$ Eds.). Handbook of communication and aging research (pp. 31-67). New York, NY: Routledge.

Ozolins, U. (2009). Back translation as a means of giving translators a voice. The International Journal for Interpreting and Translation Research, 1, 1-13.

Schellingerhout, J.M., Heymans, M.W., Verhagen, A.P., de Vet, H., Koes, B.W., \& Terwee, C.B. (2011). Measurement properties of translated versions of neck-specific questionnaires: a systematic review. BMC Medical Research Methodology, 11, 1-14.

Steverink, N., Westerhof, G., Bode, C., \& Ditmann-Kohli, F. (2001). The personal experience of aging, individual resources, and subjective well-being. Journal of Gerontology: Psychological Sciences, 56, 364-373. doi:10.1093/geronb/56.6.P364

Tabachnick, B.G., \& Fidell, L.S. (1996). Using multivariate statistics ( $3^{\text {rd }}$ Ed.). Northridge: Harper Collins College Publishers

Teh, J.K., Tey, N.P., \& Ng, S.T. (2014). Family support and loneliness among older person in multiethnic in Malaysia. The Scientific World Journal, 1-11. doi:10.1155/2014/654382 
Tohit, N., Browning, C. \& Radermacher, H. (2012. We want a peaceful life here and hereafter: healthy ageing perspectives of older Malays in Malaysia. Ageing and Society, 32, 405424. doi:10.1017/S0144686X11000316

United Nations. (2013). Department of economic and social affairs, population division world population ageing 2013. New York, NY: United Nations Publication.

Unsworth, K.L., McKee, K.J., \& Mulligan, C. (2001). When does old age begin? The role of attitudes in age parameter placement. Social Psychology Review, 3, 5-15.

Wang, C., \& Mallinckrodt, B.S. (2006). Differences between Taiwanese and US cultural beliefs about ideal adult attachment. Journal of Counseling Psychology, 53, 192-204. doi:10.1037/0022-0167.53.2.192

Wells, Y., Foreman, P., Gething, L., \& Petralia, W. (2004). Nurses' attitudes toward aging and older adults. Journal of Gerontological Nursing, 30, 5-9. doi:10.3928/00989134 20040901-04

World Population Prospect. (2017). United Nations desa /population division. Retrieved from https://esa.un.org/unpd/wpp/

World Value Survey. (2017). Online analysis 2010-2014. Retrieved from http://www.worldvaluessurvey.org/WVSOnline.jsp

Wurm, S., Tomasik, M.J., \& Tesch-Römer, C. (2010) On the importance of a positive view on ageing for physical exercise among middle-aged and older adults: Cross sectional and longitudinal findings, Psychology and Health, 25, 25-42, doi:10.1080/08870440802311314. 
Yan, T., Silverstein, M., \& Wilber, K.H. (2011). Does race/ethnicity affect aging anxiety in American baby boomers? Research on Aging, 33, 361-378 
Table 1. Demographic Information

\begin{tabular}{clllll}
\hline Characteristics & All & $18-29$ & $30-39$ & $40-49$ & $50-60$ \\
& $\mathrm{n}=911(\%)$ & $\mathrm{n}=247(\%)$ & $\mathrm{n}=356(\%)$ & $\mathrm{n}=158(\%)$ & $\mathrm{n}=140(\%)$ \\
\hline Gender & & & & \\
Men & $395(43.3)$ & $94(10.3)$ & $137(15.04)$ & $76(8.3)$ & $85(9.3)$ \\
Women & $516(56.6)$ & $153(16.8)$ & $219(24.0)$ & $82(9.0)$ & $55(6.0)$ \\
Ethnicity & & & & $140(13.1)$ \\
Malay & $852(93.5)$ & $236(25.9)$ & $341(37.4)$ & $146(16.0)$ & $119(13)$ \\
Chinese & $30(3.3)$ & $5(0.5)$ & $7(0.8)$ & $8(0.9)$ & $10(1.1)$ \\
Indian & $18(2.0)$ & $2(0.2)$ & $5(0.5)$ & 0 & $11(1.2)$ \\
Other & $11(1.2)$ & $4(0.4)$ & $3(0.3)$ & $4(0.4)$ & 0
\end{tabular}

Educational Level $^{\mathrm{a}}$

$\begin{array}{lllllr}\text { Lower } & 567(62.2) & 154(16.9) & 238(26.1) & 84(9.2) & 83(9.1) \\ \text { Higher } & 344(37.8) & 93(10.2) & 118(13.0) & 74(8.1) & 57(6.3)\end{array}$

Occupational Group

$\begin{array}{llllll}\text { Managers } & 13(1.4) & 1(0.1) & 7(0.8) & 3(0.3) & 2(0.2) \\ \text { Professionals } & 208(22.8) & 38(4.2) & 50(5.5) & 58(6.4) & 61(7.0) \\ \begin{array}{l}\text { Technicians \& Associate } \\ \text { Professionals }\end{array} & 157(17.2) & 44(4.8) & 60(6.6) & 34(3.7) & 16(1.8) \\ \text { Clerical Support } & 449(49.3) & 134(14.7) & 206(22.6) & 51(5.6) & 52(5.7) \\ \text { Service and Sales } & 38(4.2) & 14(1.5) & 15(1.6) & 5(0.5) & 4(0.4) \\ \text { Skilled, Agricultural, Forestry } & 32(3.5) & 12(1.3) & 14(1.5) & 2(0.2) & 4(0.4) \\ \text { \& Fishery } & & & & & \\ \text { Plant, Machine Operators \& } & 11(1.2) & 1(0.1) & 4(0.4) & 5(0.5) & \\ \text { Assemblers } & & & & \end{array}$


$\begin{array}{llllll}\text { Elementary Occupations } & 1(0.1) & 1(0.1) & 0 & 0 & 0\end{array}$

$\begin{array}{llllll}\text { Craft } \& \text { Trade Workers } & 0 & 0 & 0 & 0 & 0\end{array}$

$\begin{array}{llllll}\text { Missing } & 2(0.2) & 2(0.2) & 0 & 0 & 0\end{array}$

${ }^{\mathrm{a}}$ Lower education level $=($ High school OR certificate/diploma holders $)$

Higher education level $=($ Undergraduate OR postgraduate holders $)$ 
Table 2. Eigenvalues and Factor Loadings of the 25 items retained in the RAQ.

\begin{tabular}{|c|c|c|c|c|}
\hline Items/ Factors & $\begin{array}{l}\text { Negative thought } \\
\text { about growing } \\
\text { older }\end{array}$ & $\begin{array}{l}\text { Family \& } \\
\text { Religion }\end{array}$ & $\begin{array}{l}\text { Positive } \\
\text { Aspect of } \\
\text { Ageing }\end{array}$ & $\begin{array}{l}\text { Perceived } \\
\text { Personal } \\
\text { Attribute }\end{array}$ \\
\hline Variance of Factors $($ Total $=40.61 \%)$ & $20.66 \%$ & $11.07 \%$ & $6.05 \%$ & $2.83 \%$ \\
\hline I worry that I might become senile and lose my mind ${ }^{\text {a }}$ & .736 & & & \\
\hline I worry about my health getting worse ${ }^{b}$ & .707 & & & \\
\hline I worry about becoming frail ${ }^{\mathrm{a}}$ & .703 & & & \\
\hline I worry about loss of independence & .678 & & & \\
\hline I am concerned about who will care for me if I become frail ${ }^{\mathrm{a}}$ & .675 & & & \\
\hline It worries me that I won't enjoy life as much as I do now ${ }^{a}$ & .610 & & & \\
\hline I worry about the loss of loved ones around me & .599 & & & \\
\hline I worry about dying and leaving behind those I love & .513 & & & \\
\hline I worry about having less money to live on ${ }^{\mathrm{b}}$ & .497 & & & \\
\hline I won't feel as safe on my own as I do now ${ }^{\text {a }}$ & .493 & & & \\
\hline I will be more lonely than I am now ${ }^{\mathrm{a}}$ & .455 & & & \\
\hline I will enjoy having my family around me $\mathrm{b}^{\mathrm{b}}$ & & .900 & & \\
\hline I am happy that my family will take care of me ${ }^{b}$ & & .843 & & \\
\hline I will be happy that I can devote more time to my religion ${ }^{\mathrm{b}}$ & & .711 & & \\
\hline There is a lot to look forward to in regard to being old ${ }^{\mathrm{a}}$ & & & .684 & \\
\hline In my old age I will be as enthusiastic about life as I am now ${ }^{\mathrm{a}}$ & & & .661 & \\
\hline I do not feel there is much to be scared about becoming an older & & & .515 & \\
\hline person $^{\text {a }}$ & & & & \\
\hline Old age will brings satisfactions which are not available to the & & & .507 & \\
\hline
\end{tabular}


I will have more time to do the things that I enjoy ${ }^{\mathrm{b}}$

Old age will be an enjoyable time of life ${ }^{a}$

I will become more irritable and grouchy than I am now ${ }^{\mathrm{a}}$

I will be more set in my ways and reluctant to change ${ }^{\mathrm{a}}$

Others may find me difficult to get along with ${ }^{\mathrm{a}}$

I won't like growing old

I won't like looking old ${ }^{\mathrm{b}}$

${ }^{a}$ Items that loaded onto the same factors as in work done in Western populations (Gething et al., 2004; Netz et al., 2001), and that thus represent a possible 'core set' of items that could work across cultural settings

${ }^{\mathrm{b}}$ New items added 
Table 3. Internal Consistency and Correlation Matrix of the Malay Version of the RAQ.

\begin{tabular}{|c|c|c|c|c|c|}
\hline & Negative & Family \& & Positive & Perceived & \\
\hline & Thoughts about & Religion & Aspects of & Personal & Total RAQ \\
\hline & Growing Older & & Ageing & Attributes & \\
\hline & $(\mathrm{M}=2.71$ & $(\mathrm{M}=4.28$ & $(\mathrm{M}=3.47$ & $(\mathrm{M}=3.36$ & $(\mathrm{M}=3.21$, \\
\hline & $\mathrm{SD}=0.7)$ & $\mathrm{SD}=0.6)$ & $\mathrm{SD}=0.5)$ & $\mathrm{SD}=0.7)$ & $\mathrm{SD}=0.4)$ \\
\hline Reliabilities $(\alpha)$ & .89 & .84 & .73 & .82 & .88 \\
\hline Negative Thoughts about & & $-.120 * *$ & $.215 * *$ & $.544 * *$ & $.868 * *$ \\
\hline \multicolumn{6}{|l|}{ Growing Older } \\
\hline Family \& Religion & & & $.261 * *$ & $.181 * *$ & $.214 * *$ \\
\hline Positive Aspect of Ageing & & & & $.258 * *$ & $.546 * *$ \\
\hline Perceived Personal Attributes & & & & & $.773 * *$ \\
\hline
\end{tabular}

Note: Higher scores in all factors indicate more positive attitudes to ageing. 
Table 4. Means (and standard deviations) for scores on the Total RAQ and each subscale. To facilitate comparison of scores across the subscales (which differ in the number of items they contain), scores for each subscale have been reported as the mean score per item (i.e. total subscale score divided by the number of items in the subscale). Superscript letters indicate significant differences between specific levels of each factor.

\begin{tabular}{|c|c|c|c|c|c|}
\hline & Total RAQ & $\begin{array}{c}\text { Negative Thought } \\
\text { about Growing Older }\end{array}$ & $\begin{array}{c}\text { Positive Aspects } \\
\text { of Ageing }\end{array}$ & $\begin{array}{c}\text { Perceived Personal } \\
\text { Attributes }\end{array}$ & $\begin{array}{c}\text { Family and } \\
\text { Religion }\end{array}$ \\
\hline \multicolumn{6}{|l|}{ Age Group } \\
\hline $18-29$ & $78.53(0.74)^{\mathrm{a}}$ & $2.66(0.04)^{\mathrm{a}}$ & $3.35(0.04)^{\mathrm{a}, \mathrm{b}}$ & $3.29(0.05)$ & $4.22(0.04)$ \\
\hline $30-39$ & $79.85(0.64)^{\mathrm{a}}$ & $2.68(0.04)^{\mathrm{a}}$ & $3.45(0.03)^{\mathrm{a}}$ & $3.35(0.04)$ & $4.30(0.04)$ \\
\hline $40-49$ & $80.91(0.89)$ & $2.72(0.05)$ & $3.54(0.04)^{\mathrm{d}}$ & $3.39(0.06)$ & $4.25(0.03)$ \\
\hline $50-60$ & $83.97(1.04)^{\mathrm{c}, \mathrm{d}}$ & $2.92(0.06)^{\mathrm{c}, \mathrm{d}}$ & $3.60(0.05)^{\mathrm{c}, \mathrm{d}}$ & $3.47(0.07)$ & $4.28(0.03)$ \\
\hline \multicolumn{6}{|l|}{ Gender } \\
\hline Men & $81.67(0.58)^{\mathrm{e}}$ & $2.81(0.03)$ & $3.52(0.03)$ & $3.39(0.04)$ & $4.23(0.03)$ \\
\hline Women & $79.95(0.61)^{\mathrm{e}}$ & $2.68(0.04)$ & $3.45(0.03)$ & $3.37(0.04)$ & $4.30(0.03)$ \\
\hline \multicolumn{6}{|c|}{ Education Levels } \\
\hline Lower & $80.31(0.52)$ & $2.71(0.03)$ & $3.48(0.02)$ & $3.36(0.03)$ & $4.29(0.03)$ \\
\hline
\end{tabular}



Higher
$81.31(0.66)$
$2.79(0.04)$
$3.49(0.03)$
$3.40(0.04)$
$4.24(0.04)$

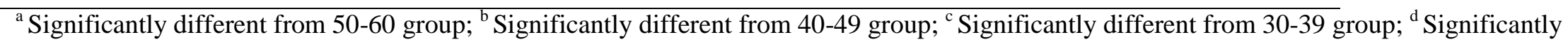
different from 18-29 group; ${ }^{\mathrm{e}}$ Significantly different between genders. 


\section{Supplemental Materials}

(i) Results of the content analysis of open-ended responses used to generate candidate new items.

\begin{tabular}{|c|c|c|c|c|}
\hline No. & Themes & $\begin{array}{c}\text { Content of Respondents' Responses (number of } \\
\text { respondents reporting each) }\end{array}$ & $\begin{array}{c}\text { Total } \\
\text { Number of } \\
\text { Respondents }\end{array}$ & $\begin{array}{c}\text { Candidate New Items } \\
\text { Developed }\end{array}$ \\
\hline 1 & Death & $\begin{array}{l}\text { - Scared of death (1) } \\
\text { - Prepare for emergency departure }(1)\end{array}$ & 2 & Not Applicable \\
\hline 2 & Physical appearance & $\begin{array}{l}\text {-Looking old (2) } \\
\text {-Wrinkled skin (2) } \\
\text {-Knee pain (1) } \\
\text {-Hair loss (1) }\end{array}$ & 6 & -I won't like looking old \\
\hline 3 & Health & $\begin{array}{l}\text {-Hoping to be well and healthy, even though } \\
\text { ageing is associated with loss (2) } \\
\text {-Worry my health will be worse (6) } \\
\text {-My ability to do something becomes } \\
\text { slow compared to young age (2) } \\
\text {-Feeling tired (1) } \\
\text {-Weak physical ability (2) } \\
\text {-Frail (2) } \\
\text {-Being careful with my food intake and daily } \\
\text { activity in order to ensure that my health is } \\
\text { good (1) }\end{array}$ & 16 & $\begin{array}{l}\text {-I worry about my health getting } \\
\text { worse }\end{array}$ \\
\hline 4 & $\begin{array}{l}\text { Ability to do desirable } \\
\text { things }\end{array}$ & $\begin{array}{l}\text { - Travel to favorite places (3) } \\
\text { - Able to do everything on my own (2) } \\
\text { - Able to work and contribute to society (2) } \\
\text { - Rest at home (2) } \\
\text { - More time for myself (1) }\end{array}$ & 10 & $\begin{array}{l}\text {-I will have more time to do the } \\
\text { things that I enjoy. }\end{array}$ \\
\hline 5 & Family relationships & $\begin{array}{l}\text {-Having more time to spend with my family (2) } \\
\text {-Hoping that my children are happy with their } \\
\text { own family (1) } \\
\text {-People that I love are still happy and are together }\end{array}$ & 18 & $\begin{array}{l}\text {-I will enjoy having my family } \\
\text { around me } \\
\text {-I am happy that my family will } \\
\text { take care of me. }\end{array}$ \\
\hline
\end{tabular}


-Getting more attention from society and children as I grow older (1)

- Children are busy with their own life (1)

- Worried that the time with my family is short as I may die (1)

- Feeling lonely as my children already have their own family and are living on their own without me (3)

- Need help from my children/family to do something

\section{Religion}

Acceptance of ageing

8

\section{Financial Concerns}

- Spend more time worshipping God (3)

- Doing good things (1)

- Being grateful to God (2)

- Accept that I am already old (3)

- Accept the ageing process (1)

-Using pension money for the rest of my life (1)

-No income / financially unstable, so I am worried about finances after retirement (3)
$6 \quad$ I will be happy that I can devote more time to my religion.

4 I will accept the fact that I am old.

$4 \quad$ I worry about having less money to live on 
(ii) The Malay Version of the RAQ

Berikut adalah penyataan tentang perasaan seseorang apabila mengalami perubahan usia. Bayangkan apa yang akan anda rasa apabila ANDA BERUSIA LEBIH 65 TAHUN. Nyatakan sejauh mana anda bersetuju/tidak bersetuju terhadap pernyataan berikut dengan menanda $(\checkmark)$ satu jawapan yang paling hampir dengan perasaan anda.

\begin{tabular}{|c|c|c|c|c|c|c|}
\hline & PENYATAAN & $\begin{array}{l}\text { Sangat } \\
\text { Tidak } \\
\text { Setuju }\end{array}$ & $\begin{array}{l}\text { Tidak } \\
\text { Setuju }\end{array}$ & Neutral & Setuju & $\begin{array}{l}\text { Sangat } \\
\text { Setuju }\end{array}$ \\
\hline 1 & $\begin{array}{l}\text { Usia tua akan menjadi masa yang menyeronokkan } \\
\text { dalam hidup }\end{array}$ & & & & & \\
\hline 2 & $\begin{array}{l}\text { Saya bimbang saya akan menjadi nyanyuk dan } \\
\text { hilang keupayaan berfikir. }\end{array}$ & & & & & \\
\hline 3 & $\begin{array}{l}\text { Saya berharap saya akan dapat mengenang kembali } \\
\text { kehidupan lalu dengan perasaan bangga }\end{array}$ & & & & & \\
\hline 4 & $\begin{array}{l}\text { Saya akan menjadi lebih sunyi berbanding } \\
\text { sekarang }\end{array}$ & & & & & \\
\hline 5 & $\begin{array}{l}\text { Usia tua membawa kepuasan yang tidak dapat } \\
\text { dinikmati ketika muda. }\end{array}$ & & & & & \\
\hline 6 & $\begin{array}{l}\text { Menjadi uzur jarang sekali menjadi isu yang } \\
\text { membimbangkan saya }\end{array}$ & & & & & \\
\hline 7 & $\begin{array}{l}\text { Saya bimbang tentang kematian dan meninggalkan } \\
\text { mereka yang saya sayang }\end{array}$ & & & & & \\
\hline 8 & $\begin{array}{l}\text { Saya risau tidak akan menikmati kehidupan seperti } \\
\text { yang saya rasai sekarang. }\end{array}$ & & & & & \\
\hline 9 & $\begin{array}{l}\text { Saya dapati pemikiran tentang penambahan usia amat } \\
\text { menyedihkan. }\end{array}$ & & & & & \\
\hline 10 & $\begin{array}{l}\text { Kehidupan boleh menjadi lebih baik apabila anda } \\
\text { melepasi umur pertengahan. }\end{array}$ & & & & & \\
\hline 11 & $\begin{array}{l}\text { Saya akan menyesali kehilangan kekuatan dan daya } \\
\text { tarikan }\end{array}$ & & & & & \\
\hline 12 & $\begin{array}{l}\text { Saya rasa tidak perlu ditakutkan sangat tentang } \\
\text { menjadi orang tua }\end{array}$ & & & & & \\
\hline 13 & $\begin{array}{l}\text { Saya bimbang hilang kebergantungan kepada diri } \\
\text { sendiri. }\end{array}$ & & & & & \\
\hline 14 & Saya jangka untuk menjadi penyayang dan prihatin & & & & & \\
\hline 15 & $\begin{array}{l}\text { Saya akan dapat menerima kematian rakan-rakan dan } \\
\text { orang yang disayangi sebagai proses semula jadi dalam } \\
\text { kehidupan. }\end{array}$ & & & & & \\
\hline 16 & $\begin{array}{l}\text { Saya ternanti-nanti untuk menjadi tua dengan } \\
\text { seseorang yang saya cintai }\end{array}$ & & & & & \\
\hline 17 & Saya bimbang menjadi uzur. & & & & & \\
\hline 18 & $\begin{array}{l}\text { Saya akan menjadi lebih cepat marah dan perengus } \\
\text { berbanding sekarang. }\end{array}$ & & & & & \\
\hline 19 & $\begin{array}{l}\text { Orang lain mungkin sukar untuk bergaul dengan } \\
\text { saya }\end{array}$ & & & & & \\
\hline 20 & Saya akan menjadi lebih terikat dengan cara saya & & & & & \\
\hline
\end{tabular}




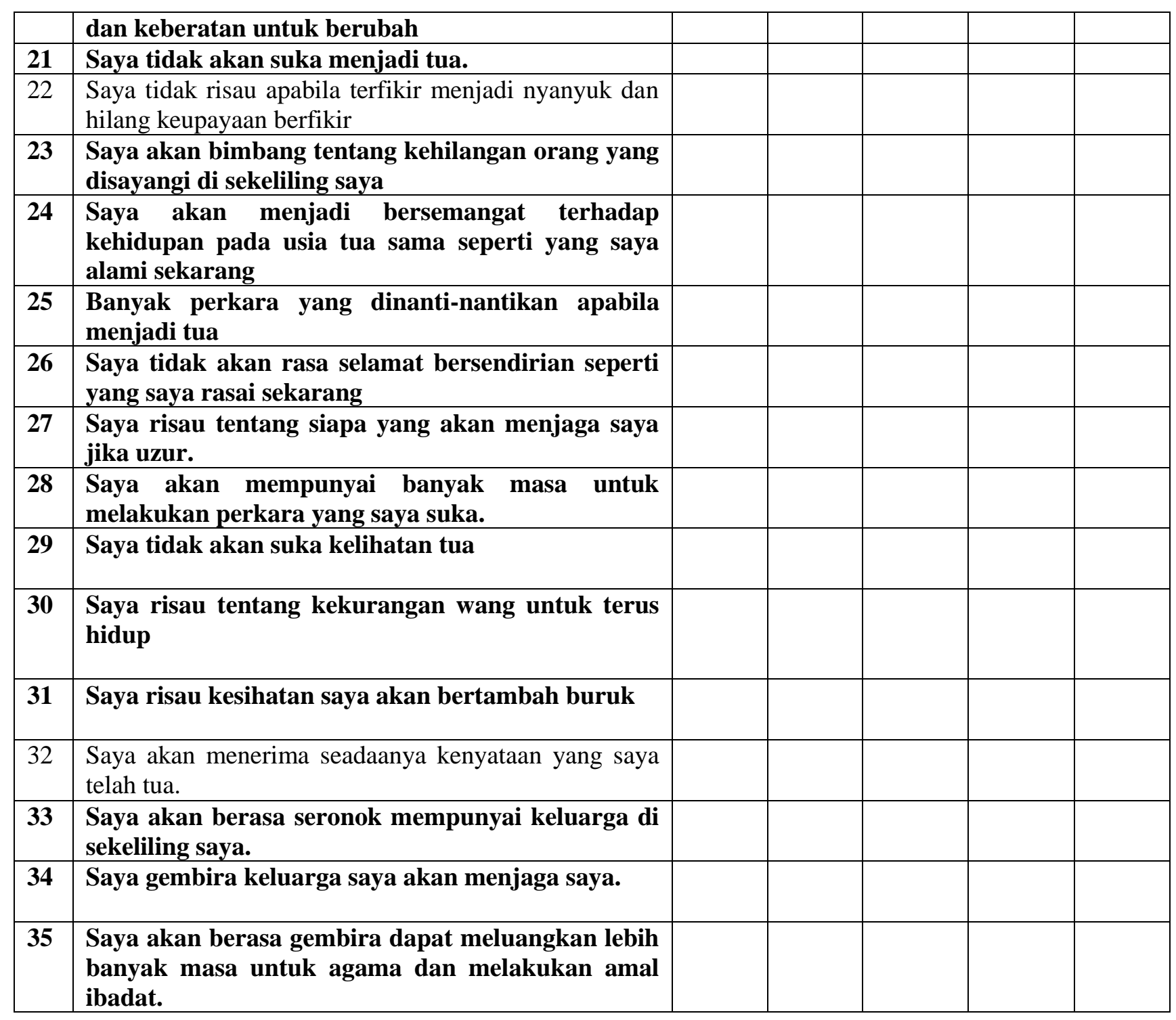

* Items in bold are those that were retained in the final version of the questionnaire. 
(iii) Factor Loadings for the Four Factor Model of the RAQ with 35 items

\begin{tabular}{|c|c|c|c|c|}
\hline \multirow[t]{2}{*}{ Items } & & \multicolumn{3}{|c|}{ Factors } \\
\hline & $\begin{array}{c}\text { Negative } \\
\text { thought } \\
\text { about } \\
\text { growing } \\
\text { older }\end{array}$ & $\begin{array}{l}\text { Family } \\
\& \\
\text { Religion }\end{array}$ & $\begin{array}{c}\text { Positive } \\
\text { aspect of } \\
\text { ageing }\end{array}$ & $\begin{array}{l}\text { Perceived } \\
\text { personal } \\
\text { attributes }\end{array}$ \\
\hline 2 I worry that I might become senile and lose my mind & .736 & .034 & -.025 & -.126 \\
\hline 31 I worry about my health getting worse ${ }^{a}$ & .707 & -.076 & -.010 & .065 \\
\hline 17 I worry about becoming frail & .703 & .048 & -.032 & -.009 \\
\hline 13 I worry about loss of independence & .678 & .064 & -.025 & .025 \\
\hline $\begin{array}{l}27 \text { I am concerned about who will care for me if I become } \\
\text { frail }\end{array}$ & .675 & -.068 & .025 & .072 \\
\hline 8 It worries me that I won't enjoy life as much as I do now & .610 & .088 & .019 & .198 \\
\hline 23 I worry about the loss of loved ones around me & .599 & -.131 & -.049 & .041 \\
\hline 7 I worry about dying and leaving behind those I love & .513 & .005 & -.032 & .159 \\
\hline 30 I worry about having less money to live on ${ }^{\mathrm{a}}$ & .497 & -.087 & .075 & .245 \\
\hline 26 I won't feel as safe on my own as I do now & .493 & -.031 & .001 & .183 \\
\hline 4 I will be more lonely than I am now & .455 & .067 & .012 & .238 \\
\hline 11 I will regret the loss of strength and attractiveness ${ }^{\mathrm{b}}$ & .416 & .077 & .010 & .345 \\
\hline $\begin{array}{l}22 \text { I do not worry about the thought of becoming senile } \\
\text { and losing my mind }{ }^{\text {b }}\end{array}$ & .404 & -.087 & .347 & -.313 \\
\hline 33 I will enjoy having my family around $\mathrm{me}^{\mathrm{a}}$ & .043 & .900 & .029 & -.078 \\
\hline 34 I am happy that my family will take care of me ${ }^{a}$ & .071 & .843 & -.057 & -.080 \\
\hline $\begin{array}{l}35 \text { I will be happy that I can devote more time to my } \\
\text { religion }^{\text {a }}\end{array}$ & .048 & .711 & .010 & .074 \\
\hline 32 I will accept the fact that I am old ${ }^{a b}$ & -.078 & .307 & .300 & .023 \\
\hline 25 There is a lot to look forward to in regard to being old & -.060 & .012 & .684 & .022 \\
\hline $\begin{array}{l}24 \text { In my old age I will be as enthusiastic about life as I } \\
\text { am now }\end{array}$ & .052 & .016 & .661 & .005 \\
\hline
\end{tabular}


12 I do not feel there is much to be scared about becoming $\quad \begin{array}{lllll}-.031 & -.031 & \mathbf{. 5 1 5} & .207\end{array}$ an older person.

5 Old age will brings satisfactions which are not

$\begin{array}{llll}-.004 & -.063 & \mathbf{. 5 0 7} & -.069\end{array}$
available to the young

28 I will have more time to do the things that I enjoy ${ }^{\mathrm{a}}$

$\begin{array}{llll}.030 & .145 & \mathbf{. 4 6 6} & -.045 \\ & & & \\ .240 & .001 & \mathbf{. 4 6 2} & .033 \\ .002 & .129 & \mathbf{. 4 4 6} & .134\end{array}$

15 I will be able to accept the death of friends and loved

.002 ones as a natural part of life ${ }^{\mathrm{b}}$

10 Life can get better once you pass middle age ${ }^{b}$

$\begin{array}{lllll}-.090 & -.012 & .433 & .045\end{array}$

6 Becoming frail is rarely an issue which concerns me ${ }^{\mathrm{b}}$

$\begin{array}{llll}.320 & -.117 & \mathbf{. 4 1 4} & -.218\end{array}$

16 I look forward to growing old with someone I love ${ }^{b}$

$-.029 \quad .166$
$.373 \quad-.004$

14 I expect to be a loving, caring person ${ }^{\mathrm{b}}$

$-.133$

.319

.336

3 I hope that I might look back on my life with a sense of

$-.230$

.199

.252

.077 pride $^{\mathrm{b}}$

18 I will become more irritable and grouchy than I am now

$\begin{array}{llll}.097 & .033 & .015 & \mathbf{. 6 9 6} \\ .096 & .006 & .022 & \mathbf{. 6 5 6} \\ .121 & .060 & -.008 & \mathbf{. 6 5 0} \\ .165 & .005 & .176 & \mathbf{. 5 8 1} \\ .249 & -.080 & .149 & \mathbf{. 4 5 9} \\ .345 & .035 & .060 & \mathbf{. 4 0 7}\end{array}$

20 I will be more set in my ways and reluctant to change.

19 Others may find me difficult to get along with

21 I won't like growing old

29 I won't like looking old ${ }^{\mathrm{a}}$

9 I find the thought of growing old depressing ${ }^{b}$

a New items added

$\mathrm{b}_{\text {Item loading }<.45 \text { (Items omitted) }}$

*Factor loadings and cross loadings of all 35 items on the four-factor model of the RAQ. Figures in bold text represent the highest loading for each item. 